\title{
The Effects of Cooperative Learning Model Type TPS and Reading Habits Toward Skills in Writing Short Story Reviews Text
}

\author{
Siska Amelia, Syahrul Ramadan, Erizal Gani \\ Universitas Negeri Padang \\ siskaamelia29051993@gmail.com
}

\begin{abstract}
This study aimed to describe the skills of writing the text of the students 'short story review which was taught by cooperative learning model of TPS type and conventional learning model, describing the skill of writing the text of the students' short story which was learned through cooperative type model of TPS high reading habits, and students who were taught by using conventional learning methods that habitually read high on the students of class VIII SMP N 1 Pariaman and described the interaction between cooperative learning model of TPS type and reading habits to the skills of writing text of students in class $V$ III SMP N 1 Pariaman. This research was a quantitative $2 \times 2$ factorial experimental design. The population of this research was the students of class VIII SMP N 1 Pariaman. Data collection was done through questionnaires and tests. Based on the result of research that cooperative learning model of TPS type influence the skill of writing text of short story. The skill of writing a review of students 'short stories taught by cooperative learning model of TPS type with high reading habits was better than the skill of writing the text of the students' short story which was taught by conventional learning model with high reading habit. There was no interaction between the TPS type cooperative learning model and reading habits in influencing the writing skills of short story text
\end{abstract}

Keywords--- effect, think pair share, conventional, reading habits, review text, short stories

\section{INTRODUCTION}

Writing skills is one of the important aspects of language skills mastered and enhanced by students (Dewi, 2013; Anggraini, Yasin \& Radjab, 2014; Iftanti, 2016). This occurs not only in Indonesia but also in other countries, such as in Columbia (Ramirez, 2013), Romania (Dumitrescu, Coman, Nutu, 2015), and in Israel (Sayag, 2016). In addition, writing skills also require an appropriate approach or learning model (Rus, 2015).

From a student perspective, writing is a difficult thing and even considered a frightening exercise to pour thought into paper by noticing the mastery of writing rules, such as spelling, citation and grammatical formats (Defazio, Jones, Tennant, \& Hook, 2010, p.34).

However, although writing is considered difficult by students, writing is a fundamental component of language. When a child writes, his experience and knowledge creates a unique meaning (Jones, Reutzel, \& Fargo in Cole \& Feng, 2015). As a result, students identify writing skills because they are more difficult than listening and reading skills (Berman \& Cheng in Cole \& Feng, 2015). Writing is a language skill that has an important role in education and knowledge. This is because science, information, and technology are found and obtained in writing. Not only plays a role in the world of education and knowledge, writing is also a language skill used to communicate and actualize themselves (Yulianti, Gani \& Tressyalina, 2018, p.88). In addition, writing is a skill that most of his students are able to acquire a new language (Nesamalar, Saratha \& Tea, in Cole \& Feng, 2015).

One of the texts studied by grade VIII junior students in accordance with the Curriculum 2013 is the review text. The text is contained in the 4th Core Competence (KI) "Try, process, and decorate in concrete realm (using, parsing, composing, modifying, and making) and abstract realm (writing, reading, counting, drawing and composing) in accordance with those studied in schools and other sources in the same point of view / theory ". 4.11 Basic Competence (KD) is "Presenting a response about the quality of the work (films, short stories, poems, novels, local artworks, etc.) in the form of review text orally and write by looking at the structure, linguistic element, or oral aspect" (Kosasih, 2017). Arnadi, Sriasih and Wisudariani $(2015$, p.2) suggest that the text of a review is a text resulting from an analysis of various things. The analysis can take the form of books, novels, news, reports, short stories, or fairy tales. The text provides responses or analysis relating to the background, time, place, and characters it contains.

Based on the observations and interviews that the researchers conducted with the Indonesian class VIII SMP N I Pariaman, Helma Susanti's mother, S.Pd., that the KKM set at SMP N 1 Pariaman for Indonesian language learning is 75 and obtained the picture that writing skills in general unpopular students. In addition, the fundamental problem faced by teachers in learning Indonesian is the lack of attention of students to the subject matter. This is because students learn more text. Students tend to be easily tired of learning Indonesian language in Curriculum 2013. Though the learning model in Curriculum 2013 requires student activeness. In addition, the source of learning is also still limited. 
The textbook used is only based on the student textbooks and teacher books provided by the school. The learning model used by teachers has not varied. Teachers rely solely on learning models with lecture and question and answer methods.

Another problem students encounter in writing review text skills is seen from the development of very simple paragraphs. For example, in the text structure of the orientation section there are only two sentences in a paragraph. In addition, in terms of language there are also mistakes, such as the use of a person's name should begin with a capital letter. In the text structure of the interpretive passage there are also errors, such as the wording of the word where it should be separated, eg 'in the canteen', 'in front of its class', 'inside'. Students are also still confused to distinguish between the text structure of part one with other parts. The problems and problems faced by students in writing review text were also expressed by previous research, such as Novitasari, Mustofa \& Karomani (2015), Meza, Mustofa \& Karomani (2015), and Arnadi, Sriasih \& Wisudariani (2015).

Aside from the problems mentioned above, the lack of reading habits also influences student learning outcomes. According to Ayhan, Simsek, and Bicer (2014, p.13-18), reading habits are essential in improving reading levels. Reading habits are defined as practicing reading action throughout life, continuously and critically as the need and source of pleasure. This is in line with the opinion of Palani (2012, p.90) which states that reading habits are an important aspect for a society that is useful in shaping individual personalities, helping to develop the right mindset and create new ideas.

School literacy movement is also very helpful to improve students' reading habits. At SMP N 1 Pariaman, literacy movements are conducted every Tuesday and Wednesday in the morning. The activity takes about fifteen minutes before the lesson begins. Students are asked to rewrite any reading material they read, either novels, books, or other works.

However, based on interview researchers with some students, there are also some students who started their literacy activities at home. They first write the reading material to be written at home. When at school, they no longer do literacy.

From the various problems that have been described, researchers chose to use one of the cooperative learning model that can make students become more active and not easily bored in learning activities. The model is a type ofcooperative model think pair share (TPS). TPS is a learning technique that provides time to process and build to increase the depth and breadth of thinking. Using TPS techniques, students think about the rules they share with partners and with classmates in groups (Wasillah, Ramadhan \& Noveria, 2016). Much research has been done on the use of cooperative learning models of TPS types, such as in Malaysia by Azlina (2010), in the United States by Kaddoura (2013); Sampsel (2013), in India by Dol (2014), in Nigeria by Ibe (2009); Bamiro (2015); Martha, Emmanuel \& Seraphina (2015), in Taiwan by Chun \& Lee (2015), in Myanmar by Tint \& Nyunt (2015), in Japan by Uno \& Katayama (2017), in Arabia by Hamdan (2017), in Palestine by Raba (2017), in Turkey by Othman and Othman (2012), and in Indonesia by Siburian (2013); Sumarsih \& Sanjaya (2013); Usman (2015); Hasibuan (2016); Pradana \& Pramudya (2017); Sumarni (2016); Desta (2017); Nasution \& Surya (2017); and Tendrita, Mahanal, \& Zubaidah (2017). The researchers examined how impacts, impacts, applications, and outcomes derived from the use of the TPS type cooperative learning model.

However, it turns out that the cooperative learning model of TPS type has not been fully able to improve the learning outcomes of learners. Emerson, English, and McGoldrick (2015, p.1) suggested that the experimental group of experimental classrooms using cooperative learning model of TPS was not better than the students in the control class group. Similarly, there was no difference in the size of learning interest and attitudes toward the subjects between the experimental and control groups.

In Indonesia, the use of learning models used by Indonesian language teachers also influences the learning outcomes of learners (Adnyani Natajaya, \& Sunu, 2014; Fatimah, 2015; Astini, Sriasih, \& Indriani, 2016; Savitri, 2017). In addition, the varied learning model can eliminate boredom and boredom of learners, especially in the 2013 curriculum that the implementation of text-based learning.

From the various problems that researchers have pointed out earlier, it can be concluded that the skills of students in writing text reviews, especially writing the text of the short story reviews still have problems, both in terms of language and paragraph development. In addition, the learning model used by teachers is also still using the lecture method so that students feel quickly saturated and bored. Therefore, the researcher uses cooperative learning model of TPS type so that students become more active, not easily saturated, and students can also cooperate with their friends.

Based on the description, the purpose of the study as follows. First, to describe the skill of writing the text of the students' short story review using cooperative learning model of TPS type, with the students taught by using conventional learning method in the students of grade VIII SMP N 1 Pariaman. Second, to describe the skill of writing the text of the students who have high reading habits are taught using cooperative learning model of TPS type with students who have high reading habits are taught by using conventional learning method in grade VIII students of SMP N 1 Pariaman. Third, describe the interaction between cooperative learning model of TPS type and reading habits on the skill of writing the text of the students of class VIII SMP N 1 Pariaman. 


\section{METHODS}

The population of this study consists of all students of class VIII SMP N 1 Pariaman registered in the academic year 2017/2018, which amounted to 187 people in six classes. Sampling in this research was done by using random sampling technique -determining experiment class and control class randomly by draw technique. From the draw, it was found that the students of class VIII 4 as the experimental class, with the number of 32 people and class VIII 5 as the control class with the number of 30 people. Based on normality test and sample sample homogeneity, it was found that both classes are normal and homogeneous distributed.

The research method used in this research was experimental method with quasi experiment type (quasi experiment). The purpose of this quasi experiment was to obtain information from the experiment based treatments (treatments) to a trial unit within the design limits specified in the experimental class, in order to obtain data to illustrate what is expected. The design used in this research was $2 \times 2$ factorial design.

This study consists of three variables. First, the independent variable (independent variable) is a TPS type cooperative learning model. Second, the dependent variable (dependent variable) is the skill of writing short story reviews. Third, the moderator variable is the habit of reading. The data used in this study, first, the score of the results of the reading habit questionnaire. Second, the score of the skill test results in writing the students' short story reviews using the TPS learning model and the conventional method. Third, the score of skill test result writing of short story reviews using cooperative learning model of TPS type. Fourth, the score of skill review test results of text of the short story using conventional method.

The instrument used to collect data in this study consists of two instruments, namely the questionnaire and performance test. The questionnaire was used to know reading habits while the performance test is used to measure the skill level of students in writing short story text. Research procedure conducted by the researcher, that is first, the questionnaire was arranged based on predetermined indicator. Second, the questionnaire was validated first by one of the lecturers of FBS UNP, ie Dr. Tressyalina, M.Pd. Third, the questionnaire was tested to grade VIII 6 students, the questionnaire consisted of 40 statements and after being tested, obtained 38 valid statements and 2 invalid statements. Data declared valid when $r_{\text {table }}<r_{\text {count }}$. Fourth, after obtaining validity, then the next step is to determine whether the data is reliable or not. Based on the research that has been done, it can be concluded that the questionnaire is declared reliable because $\mathrm{r}_{\text {table }}<\mathrm{r}_{11}$, ie $0.6<1.0371$. Fourth, the valid statement was distributed to the experimental class and control class.

The test to write the text of the short story reviews in this research was in the form of performance text. Students are asked to write a short story text on the short story the teacher has provided. The steps in composing the test instrument write the text of the short story reviews, as follows. First, making the gratings based on indicators. Second, choose the short story and arrange the question or command in accordance with the test indicator. Third, conduct a rational analysis to see the suitability of the item with the measured aspect. Fourth, create a skill assessment rubric for writing short story reviews. Fifth, make the Learning Implementation Plan (RPP) and the skills test instrument writing short story text. Sixth, the Learning Implementation Plan (RPP) and the skill test writing tool of the short story review were validated and consulted with the validator lecturer, Dr. Tressyalina, M.Pd. In addition, the Learning Implementation Plan (RPP), and research instruments were also shown to teachers of Indonesian language in SMP Negeri 1 Pariaman, namely Helma Susanti, S.Pd.

\section{FINDING AND DISCUSSION}

In this section will be described three things about the research results. First, the skill of writing the text of the students' short story which is taught by cooperative learning model of TPS type and conventional learning model. Secondly, the skill of writing a review of the students' short story reading is taught by the TPS type cooperative learning model and the conventional learning model. Third, the interaction between reading habits and contextual approaches in influencing the skill of short story text writing skills.

\section{Short Story Writing Skills Students Learned by Cooperative Learning Model TPS Type and Conventional Learning Model}

The first hypothesis test showed that in general, the skills of writing text of students' short stories in the experimental class taught by cooperative learning model of TPS type is better than the skill of writing the text of the student short story in control classes taught by conventional methods. This is seen from the results of the calculation of the first hypothesis test that shows $\mathrm{t}_{\text {arithmetic }}=3.07$ and $\mathrm{t}_{\text {table }}=1.67$ at the real level of 0.05 and $\mathrm{dk} 60$. The calculation results show that $\mathrm{H}_{1}$ accepted because $t_{\text {arithmetic }}>t_{\text {table }}$.

TPS type cooperative learning model can influence students' mind patterns. Model of cooperative learning type of TPS provides an opportunity for students to think individually, helping each other with friends in pairs so that the interaction between the couple is running well. TPS type cooperative learning model is an effective way to create variations in the atmosphere of class discussion patterns. In this case, the application of the TPS type cooperative 
learning model in the classroom learning process can help students understand the concepts, theories and other provisions in an easy way (Trianto, 2011, p.81).

Kaddoura (2013, p.4) suggests that teaching and learning strategies with cooperative learning models of this type of TPS have three stages: (1) thinking stage, teachers stimulate students' thinking with questions. Then the students are given a few minutes to think about the question, (2) in pairs, at the stage students are directed to pair. Students pair up to talk about each other's answers. They compare mental or written records and identify the best answers they have thought, the answer is also the most convincing, (3) the sharing stage, after students talk in pairs for a few minutes, the teacher calls some couples to share their thoughts.

The test given to the students is a performance test, which is a test of writing short story reviews conducted in the experimental class and control class. The form of tests given in the two classes is the same, the short story used is the same and there is no difference at all. This test was conducted to see the effect of the application of cooperative type model of TPS to the skills of writing the text of the students of the class VIII SMP N 1 Pariaman.

The learning process in the experimental class is more active than the learning process in the control class. In the experimental class, students in pairs actively discuss what the teacher is instructing. In addition, students are also more confident in expressing opinions, answering questions, and being active in class discussions. Students also do not feel embarrassed, even all students spirit in following the learning process. Unlike students taught by conventional methods, students play a passive and not too active because the learning process runs with one-way communication. Learning is only centered on the teacher because the method used is identical with the lecture method, question and answer, and task assignment (Sanjaya, 2006). In addition, students only receive information provided by the teacher. Therefore, students feel bored and quickly feel bored in the learning process, especially when students are told to read short story text.

Based on the description, it can be concluded that the results of research and data analysis indicate that cooperative learning model of TPS type can give influence and positive impact to the skill of writing text of short story. The application of this type of cooperative learning model of TPS also makes students more active in learning, making it easier for students to understand the material, and giving students equal opportunities to think individually and discuss in pairs. The result of the experimental test of the experimental class students taught by using TPS type cooperative learning model is higher than the result of the student performance test that was taught by using conventional method.

\section{Short Story Writing Skills Students with High Reading Habits Learned by Cooperative Learning Model of TPS and Conventional Methods}

The second hypothesis test shows that in general, the skill of writing a review of a student's short story is a high reading in an experimental class taught by a TPS type cooperative learning model better than a skill writing a review text of a student's high-reading reading on a control class taught by a conventional method. This can be seen from the results of the hypothesis test calculation showing $\mathrm{t}_{\text {count }}=4.10$ and $\mathrm{t}_{\text {table }}=1.75$ at the real level of 0.05 and $\mathrm{dk} 15$. The calculation results show that $\mathrm{H}_{1}$ accepted because $\mathrm{t}_{\text {count }}>\mathrm{t}_{\text {table }}$.

Model of cooperative learning type of TPS can improve the ability to write text clever students read high reading. This is in accordance with the principles of cooperative learning as suggested by Johnson and Johnson (in Morgan and Keitz, 2010, p.2) suggests that there are five elements in the cooperative learning model, including: (a) positive interdependence, ie creating feelings that the group "sinks or swim together ", (b)interaction face-to-face, ie each team must sit adjacent, then eye-to-eye, (c) individual accountability, ie everyone should know the material, (d) social skills, students should work in applying selected social skills and instructors should monitor their use, (e) processing, the opportunity to reflect on how well they function as a team and whether they can be better for the next.

Control classes that apply conventional learning methods place students as learning objects that act as passive recipients. Learning in this lesson is more individual, theoretical, and abstract, knowledge is constructed by others and obtained by memorization and exercises (Sanjaya, 2006, p.259). This results in students who have low reading habits are not interested to follow the learning well. In conventional learning, students' opportunities to express their ideas are limited and students do not experience directly the process of casting ideas into good news.

Based on the previous explanation, it can be concluded that the result of the skill of writing the text of the short story students review high reading comprehended with the cooperative learning model of TPS type is better than the students with high reading habits taught by conventional method.

\section{Interaction between Reading Habits and Cooperative Learning Model of TPS Type in Influencing Text Writing Skills Brief Review}

Results Two-way ANOVA calculations for testing the fourth hypothesis show that there is no interaction between cooperative learning model of TPS type with reading habit in influencing the skill of writing short story text. That is, the main influence of the model of cooperative learning model of TPS type and reading habits each run independently in influencing the skill of writing short story text. It can be concluded that there is no influence from the 
interaction of cooperative learning model of TPS type and reading habit category in influencing the skill of writing short story text. Many other factors that can be a supportive skill to write text short story reviews, such as talent, intelligence, and others.

The lack of interaction between the TPS type cooperative learning model and reading habits occurs in both reading habits, both with high reading habits, and those with low reading habits. The absence of such interactions means that each factor of the TPS type cooperative learning model and reading habits are not interdependent with one another in influencing the writing skills of the students' short story and control class reviews. However, the TPS type cooperative learning model is more effectively applied to both levels of reading habits.

\section{CONCLUSION AND RECOMMENDATION}

Based on the research findings can be summarized as follows. First, the skill of writing a review of the students 'short stories taught by the TPS type cooperative learning model is higher than the skill of writing the text of the students' short story which is taught by the conventional method. It is evidenced that the average value of the experimental class of 81.42 is in the Good Qualification (B) while the average value of control class 64.63 is in Enough qualification (C). Second, the skill of writing a review of students' high-reading students' reading highs taught by cooperative learning model of TPS type is higher than the skill of writing the text of the students' short story which is taught by conventional method. It is proved that the average grade of experimental class reading 85.80 is high in Good Qualification (B) whereas the mean grade of control class with high reading habits of 69.44 is in the More than Enough (Ldc) qualification. Third, there is no interaction between the cooperative learning model of TPS type and reading habits in influencing the writing skills of short story text. Suggestions addressed to the parties as follows. First, for schools to improve the management of education in schools that can be done by providing learning facilities needed for the development of student potential and fluency of teaching and learning process, such as providing new books as a new source of reading to support students' skills in reading and write. Second, to the teachers of Indonesian language and Literature SMP N 1 Pariaman are recommended to provide a variety of learning models and interesting to avoid the boredom and saturation of students in learning. Third, to the students of SMP N 1 Pariaman should practice earnestly in learning, so that later skilled in the language not only skilled in reading but also skilled to four other aspects of language that is, listening, speaking, and writing.

\section{References}

Adnyani,N.M.S., Natajaya, I.N., \& Sunu, I.G.K.A. (2014). Pengaruh model pembelajaran kooperatif tipe STAD terhadap hasil belajar bahasa Indonesia ditinjau dari motivasi belajar siswa. e-Journal Program Pascasarjana Universitas Pendidikan Ganesha Program Studi Administrasi Pendidikan. 5, 1-10.

Anggraini, Y., Yasin, A., \& Radjab, D. (2014). Improving students writing skill of narrative text through video at grade XII IPA 2 of SMAN 2 Bukittinggi. Journal English Language Teaching (ELT), 2 (2), 78-91.

Arnadi, Pt., D., Sriasih, S.A., Pt \& Wisudariani, N.Md., R. (2015). Media guru dalam pembelajaran menulis teks ulasan di kelas VIII SMP N 2 Singaraja. e-Journal JPBSI Undiksha. 3, (1), 1-12.

Astini, K.R.A., Sriasih, S.A.P., \& Indriani, M.S. (2016). Penerapan teknik TPS untuk meningkatkan kemampuan menulis teks diskusi siswa kelas VIII.2 SMP N 2 Singaraja. e-Journal JPBSI Undiksha. 4, (2). 1-12.

Ayhan, A. B., Simsek, S., \& Bicer, A.M. (2014). An analysis of children's attitudes towards reading habits. European Journal of Research on Education (online). 13-18, ISSN:2147-6284.

Azlina, N.A.K. (2010). CETLs : Supporting collaborative activities among students and teachers through the use of think-pair-share techniques. IJCSI International Journal of Computer Science, 7,(5), 18-29, ISSN (Online): 1694-0814. www.IJCSI.org.

Bamiro,A. O. (2015). Effects of guided discovery and think pair share strategies on secondary school students' achievement in chemistry. SAGE Open-1-7, DOI: 10.1177/2158244014564754 sgo.sagepub.com.

Chun, S.H., Reynolds, \& Lee, R.B. (2015).Teaching adolescents EFL by integrating think-pair-share and reading strategy instruction: a quasi-experimental study. RELC Journal: A Journal of Language Teaching and Research, 46, (3), 221-235, ISSN-0033-6882.

Cole, J. \& Feng, J. Effective strategies for improving writing skills of elementary english language learners. Chinese American Educational Research and Development Association Annual Conference, 1-25.

Defazio, J., Jones, J., Tennant, F. \& Hook, S.A. (2010). Academic literacy: the importance and impact of writing across the curriculum-a case study. Journal of the Scholarship of Teaching and Learning, 10, (2), 34 - 47.

Desta, R.A. (2017). Think pair share technique in teaching speaking skill. Research in English and Education (READ), 2(1), 37-46.

Dewi, N.L.P.E.S. (2013). Meningkatkan kemampuan menulis mahasiswa dengan pengintegrasian powers dalam asessmen portofolio elektronik. Jurnal Pendidikan Indonesia, 2, (2), 244-254.

Dol, S. M. (2014). TPS (Think-Pair-Share) : An active learning strategy to teach theory of computation course. 
International Journal of Educational Research and Technology, 5, (4), 62-67, ISSN 0976-4089; E-ISSN $2277-$ 1557.

Dumitrescu, C.I., Coman, M.L., \& Nutu, I.C. (2015). Improving functional texts writing skills in english as a foreign language. ELSEVIER, 168-172.

Emerson, T.L.N., English, L.K., \& McGoldrick K.M. (2015). Evaluating the cooperative component in cooperative learning: a quasi-experimental study. Journal of Economic Education. 46(1), 1-13. ISSN: 0022-0485 /21524068. (Online). Doi: 10.1080/00220485.2014.978923.

Fatimah, N. (2015). Implementasi cooperative learning tipe think-pair-share dalam pembelajaran bercerita di Sekolah Menengah Pertama. Jurnal Penelitian Humaniora, 16, (2), 90-98.

Hamdan, R.K.A. (2017). The effect of (think-pair-share) strategy on the achievement of third grade student in sciences in the educational dsitrict of Irbid.

Hasibuan, A.Y. (2016). Pengaruh model pembelajaran TPS terhadap kemampuan memahami unsur intrinsik cerpen pada siswa kelas X SMA N 8 Padang Sidimpuan. 1, (1), 25-31, ISSN 2541-3775.

Ibe, H.N. (2009). Metacognitive strategies on classroom participation and student achievement in senior secondary school science classrooms. International Council of Associations for Science Education. 20, (1/2), 25-31.

Iftanti, E. (2016). Improving strudent's writing skills through writing writing journal articles. Lingua Scientia. 8, (1), 122.

Kaddoura, M. 2013. (2013). Think pair share: a teaching learning strategy to enhance students' critical thinking. Educational Research Quartely, 36, (4), 3-24.

Kosasih, E. (2017) Buku Guru Bahasa Indonesia Kelas VIII. Jakarta: Pusat Kurikulum dan Perbukuan, Balitbang, Kemendikbud.

Martha, C.M., Emmanuel , O.I., \& Seraphina, K.M. (2015). Effect of think-pair-share strategy on secondary school mathematics students' achievement and academic self-esteem in fractions. www.americanij.com, 2, (2), ISSN 2349-4425.

Meza, Y. F., Mustofa, A., \& Karomani (2015). Pembelajaran menulis teks ulasan pada siswa kelas VIII SMP N 4 Metro. Prodi Pendidikan Bahasa dan Sastra Indonesia FKIP Universitas Lampung, 3, (6), 1-9.

Morgan, B.M. \& Keitz, R. A. Cooperative learning effectiveness with undergraduate hispanic students. (2010). National Forum Of Multicultural Issues Journal, 7, (1), 1-8.

Nasution, Y.S. \& Surya, E. (2017). Application of TPS type cooperative learning in improving student's mathematics learning outcomes. International Journal of Sciences: Basic and Applied Research (IJSBAR). 34, (1), 116-125. ISSN 2307-4531 (Print \& Online).

Novitasari, E., Mustofa, A., \& Karomani. (2015). Kemampuan menulis teks ulasan/resensi siswa kelas VIII SMP N 2 Kotagajah. Jurnal Prodi Pendidikan Bahasa dan Sastra Indonesia FKIP Universitas Lampung. 3. (3). 3-12.

Othman, M. \& Othman, M. (2012). The proposed model of collaborative virtual learning environment for introductory programming course. Turkish Online Journal of Distance Educatio-TOJDE. 13, (1). 100-111.

Palani, K.K. (2012). Promoting reading habits and creating literate society. Journal of Art, Sains and Commerce, (online). III 2, (1), 90-94, ISSN: 2231-4172.

Pradana, O.R.Y., Sujadi, I., \& Pramudya, I. (2017). Think pair share with formative assessment for junior high school student. International Conference on Mathematics and Science Education (ICMScE) IOP Conf. 1-7. Series: Journal of Physics: Conf. Series 895 (2017) 012032 doi :10.1088/1742-6596/895/1/012032.

Raba, A.A.A. (2017). the influence of think-pair-share (TPS) on improving students' oral communication skills in EFL classrooms. Creative Education, http://www.scirp.org/journal/ce , 8, 12-23, ISSN Online: 2151-4771, ISSN Print: 2151-4755.

Ramirez, Y.E.H. (2013). Writing skill enhancement when creating narrative texts through the use of collaborative writing and the storybird web 2.0 tool. Colomb. Appl. Linguist. J. 15, (2), 166-183.

Rus, D. (2015). A didactic approach to writing skills in a technical learning environment. ELSEVIER, 1191-1196.

Sampsel, A. (2013). Finding the effects of think-pair-share on student confidence and participation. Bowling Green State University ScholarWorks, 2-19.

Sanjaya, W. (2006). Strategi Pembelajaran-Berorientasi Standar Proses Pendidik. Jakarta: Kencana Prenada Media Group.

Savitri, R. (2017). Pengaruh penerapan model pembelajaran kooperatif tipe TPS terhadap hasil belajar ekonomi. Economica Journal, 2(1), 22-27. ISSN: 2302-1590.

Sayag, E.C. Student teachers across the curriculum learn to write feedback does it reflect on their writing?. (2016). The Journal of Effective Teaching an Online Journal Devoted to Teaching Excellence, 16, (2), 5-19.

Siburian, T.A. (2013). Improving students' achievement on writing descriptive text through think pair share. International Journal of Language Learning and Applied Linguistics World (IJLLALW), 3, (3), 30-43, EISSN: 2289--- 2737 \& ISSN:2289--- 3245.

Sumarni, S. (2016). Think pair share effect of understanding the concept and achievement. Proceeding The $2 n d$ 
International Conference On Teacher Training and Education Sebelas Maret University, 2, (1), ISSN : 25002 $-4124$.

Sumarsih \& Sanjaya, D. (2013). TPS as an effective technique to enhance the students' achievement on writing descriptive text. Canadian Center of Science and Education, 6, (12), 106-113, ISSN 1916-4742 E-ISSN 19164750.

Tendrita, M., Mahanal, S., \& Zubaidah, S. (2017). Pembelajaran reading concept-map think pair share (REMAP TPS) dapat meningkatkan hasil belajar kognitif. (Online) http://journal.um.ac.id/index.php/jptpp/ EISSN: 2502-471X DOAJ-SHERPA/RoMEO-Google Scholar-IPI. 2, (6), 763-767.

Tint, S.S., Nyunt, E.E. (2015). Learning strategy with groups on page based students' profiles. Advanced Computational Intelligence: An International Journal (ACII), 2, (1), 1-19.

Trianto.(2011). Mendesain Model Pembelajaran Inovatif-Progresif. Bandung: Kencana.

Uno, M., Katayama, Y. (2017). Learning outcomes using cooperative learning in communication classes: evaluation using text analysis. Open Journal of Nursing. 7, 1058-1068, ISSN Online: 2162-5344, ISSN Print: 2162-5336.

Usman, A. (2015) . Using the think-pair-share strategy to improve students' speaking ability at Stain Ternate. Journal of Education and Practice www.iiste.org, 6, (10), 37-45, ISSN 2222-1735 (Paper) ISSN 2222-288X (Online).

Wasillah, T, Ramadhan, S \& Noveria, E. (2016). Pengaruh model pembelajaran kooperatif tipe think pair share terhadap keterampilan menulis naskah drama satu babak siswa kelas VIII SMP Negeri 30 Padang. Jurnal Pendidikan Bahasa \& Sastra Indoneisa, 5, (1), 9-16.

Yulianti, Gani, E \& Tressyalina. (2018). Korelasi keterampilan memahami teks laporan hasil observasi dan keterampilan menulis teks laporan hasil observasi. Jurnal Pendidikan Bahasa dan Sastra Indonesia, 1, (7), 8896. 